\title{
Roots nodulation, yield and yield contributing parameters of mungbean cultivars as influenced by different Phosphorous level in Swat-Pakistan
}

Imran $^{1,5 *}$, Izaz Hussain ${ }^{1}$, Inayat khattak ${ }^{1}$, Aziz Ur rehman ${ }^{2}$, Fayaz Ahamd $^{3}$, Hayat Zada ${ }^{4}$ and Shahida Naveed ${ }^{6}$

1. Department of Agronomy, The University of Agriculture, Peshawar, Pakistan

2. Plant breeding and genetics, The University of Agriculture, Peshawar, Pakistan

3. Agriculture Research Officer ARI (N) Swat.

4. Department of plant protection, The University of Agriculture, Peshawar, Pakistan

5. Incharge Agriculture Officer, Matta Circle \& District Field Agronomist IAO (Istituto Agronomico Perl,Oltremere)

Project ADP Swat II (GECOHO)

6. Department of Botany, Government Girls Degree College, Karak

*Corresponding author's email: imranagrarian@aup.edu.pk

\section{Citation}

Imran, Izaz Hussain, Inayat khattak, Aziz Ur rehman, Fayaz Ahamd, Hayat Zada and Shahida Naveed. Roots nodulation, yield and yield contributing parameters of mungbean cultivars as influenced by different Phosphorous level in Swat-Pakistan. Pure and Applied Biology. Vol. 4, Issue 4, 2015, pp 557-567.

http://dx.doi.org/10.19045/bspab.2015.44015

Received: 03/08/2015

Revised: 03/11/2015

Accepted: 12/11/2015

\section{Abstract}

Field experiment was carried out at agriculture extension demonstration plot Matta Swat Pakistan, in summer 2014. The study was conducted to evaluate the influence of different phosphorous levels on growth and yield of mungbean cultivars. The experiment was established in a randomized complete block design with three replications. Six levels of phosphorous (15.5 $\left.\% \mathrm{P}_{2} \mathrm{O}^{5}\right)$ in the form of single super phosphate (SSP) $\left(0,20,40,60,80\right.$ and $\left.100 \mathrm{~kg} \mathrm{ha}^{-1}\right)$ and three cultivars of mungbean (SWAT-I, SWAT-II and NM-54) was used for this experiment. Application of phosphorous fertilizer was significant for all parameters. Plots treated with $80 \mathrm{~kg}$ $\mathrm{P} \mathrm{ha}^{-1}$ produced maximum nodules plant ${ }^{-1}$ (25), seeds per pod (11), weight of 1000 seeds (40.2 $\mathrm{g}$ ) seed yield $\mathrm{kg} \mathrm{ha}^{-1}$ (1139) and harvest index (28.6\%) as compared to the control plots, while seeds per pod, 1000 seeds weight, seed yield and harvest index \% was statistically at par when plots treated with $100 \mathrm{~kg} \mathrm{P}^{-1}$. The cultivar SWAT-I had the highest nodules per plant (21), seeds per pods ${ }^{-1}(11)$, weight of 1000 seeds $(38.4 \mathrm{~g})$, seed yield $\mathrm{kg} \mathrm{ha}^{-1}\left(1030^{-1}\right)$ and harvest index (28.2\%) as compared to other sowed cultivars. It could be concluded from this investigation that cultivar SWAT-I treated with $80 \mathrm{~kg} \mathrm{P}_{2} \mathrm{O}_{5}$ improved the productivity and roots nodulation as compared to other tested cultivars and therefore it is advisable for the general practice under the agro-climatic conditions of the Swat Valley.

Keywords: Mungbean; Phosphorous; Cultivars; Nodule; Seed yield; Yield components. 


\section{Introduction}

Mungbean (Vigna radiata L.) is an important pulse crop with short duration of Pakistan. It is highly used for its rich content in proteins $24 \%$ with high digestibility than soybeans [1]. Mungbean contains 1-3\% fat, $50.4 \%$ carbohydrate, $3.5-4.5 \%$ fiber and $5.5 \%$ ash, while calcium and $\mathrm{P}_{2} \mathrm{O}_{5}$ are 132 and $367 \mathrm{mg}$ per 100 grams of seed, respectively [2]. Mungbean is one of the most important kharif crops and conventionally cultivated in Pakistan [3]. Mungbean in Pakistan had grown over an area of 137.4 hectares with average production 76.2 tons per hectare in the year of 2011. In Khyber-Pakhtunkhwa the mungbean are grown by 8.5 hectares with an average yield $600 \mathrm{~kg} \mathrm{ha}^{-1}[4]$. Our farmers have a wrong concept that mungbean, be like a legume crop doesn't need fertilizers. Phosphorous plays a substantial role in the formation and translocation of carbohydrates, root development, maturation of crops and resistance to pathogens. Thus the $\mathrm{P}_{2} \mathrm{O}_{5}$ increases the yield and improves quality of mungbean [6]. The protein contents of mungbean are increases with frequent supply and absorption of $\mathrm{P}_{2} \mathrm{O}_{5}$ and nitrogen [6]. Growth and development of crops depend largely on the development of the root system. Phosphorous is one of the essential nutrient amongst the three macronutrients that plants get from the soil. $\mathrm{P}_{2} \mathrm{O}_{5}$ is an important component of compounds whose functions relate to growth, root development, flowering and ripening [7]. The majority of land worldwide is deficient in $\mathrm{P}_{2} \mathrm{O}_{5}$ [8]. Pakistan's soils are generally calcareous and alkaline in nature. These types of soils usually contain trace elements. In addition, with the introduction of high-yield cultivars, crop intensity further reduced the nutrient status of the soil [9]. Therefore, the effect of $\mathrm{P}_{2} \mathrm{O}_{5}$ on roots growth, development and dense rooted system is well-known [10].
Adding fertilizer $\mathrm{P}_{2} \mathrm{O}_{5}$ improve the development of roots, which improve the act of other nutrients and water to the growing parts of the plants, causing increased photosynthetic material production and dry matter portioning. The application of $\mathrm{P}_{2} \mathrm{O}_{5}$ to mungbean has noted increasing the dry matter yield, the number of pods per plant, seeds pod $^{-1}, 1000$ seed weight, seed yield and total biomass [11]. The yield and quality of mungbean can be improved by applying the best agronomic practices and the use of high yield cultivar. Mungbean cultivars vary in yield and yield components. [12] Reported that our results were significantly different and variation was found in mungbean cultivar for yield. SWAT-II over due to the higher number of pod bearing tree branches $^{-1}$ whereas NM-54 had optimum number of pods and seeds however, [13] found statistical difference among the components of yield of mungbean cultivars under observation. [14] Found significant differences in yields and yield components of different mungbean cultivars. Keeping in view the importance of $\mathrm{P}_{2} \mathrm{O}_{5}$ application and mungbean cultivars, this research was designed to study the effect of $\mathrm{P}_{2} \mathrm{O}_{5}$ on yield and yield components of mungbean cultivars.

\section{Materials and Methods}

The experiment was established in a randomized complete block design with three replications. Six levels of phosphorus $\left(15.5 \% \mathrm{P}_{2} \mathrm{O}_{5}\right)$ in the form of single super phosphate (SSP) $(0,20,40,60,80$ and 100 $\mathrm{kg} \mathrm{has}{ }^{-1}$ ) and three cultivars of mungbean (SWAT-I, SWAT-II and NM-54) were used with $3 \mathrm{~m} \mathrm{x} 3 \mathrm{~m}$ in width and $30 \mathrm{~cm}$ row to row distance with 10 rows. Nitrogen was applied at the rate of $30 \mathrm{~kg} \mathrm{ha}^{-1}$ in the form of urea at the time of sowing. Seeds of these cultivars (SWAT-I, SWAT-II and NM-54) were sown in the $2^{\text {nd }}$ week of June at the rate of $20 \mathrm{~kg} \mathrm{ha}^{-1}$. Agronomic practices were carried out in a uniform 
manner for all experimental units throughout the growing season. Plant nodules at the moment of initiation of pods were counted. Five plants eradication randomly were taken in every subplot and then averaged. Number of pods plant ${ }^{-1}$ was counted for 10 randomly selected plants in each subplot. Seeds pod ${ }^{-1}$ was recorded by counting the seed in ten randomly selected capsules in each sub plot. After threshing 1,000 seeds weight (g) were recorded from three different seed lots and weighed with the help of an electronic balance. Four central rows in each sub plots were harvested, threshed and sun dried. Seed weight was taken with the help of an electronic balance and then converted to $\mathrm{kg}$ $\mathrm{ha}^{-1}$ with the following formula.

Seed yield $\left(\mathrm{kg} \mathrm{ha}^{-1}\right)=$

Seeds weight in four rows $(\mathrm{kg}) \times 10,000 \mathrm{~m}^{2}$

No of rows $x$ row length $x$ R-R

Harvest index was calculated using the following formula.

Harvest index $(\%)=$

Seed yield $\left(\mathrm{kg} \mathrm{ha}^{-1}\right) \times 100$

Biological yield $\left(\mathrm{kg} \mathrm{ha}^{-1}\right)$

All data collected were subjected to analysis of variance (ANOVA) with the help of statistical software, 8.0 Statistix USA [23]. F-Test on at least meaningful significance difference (LSD) test was used for comparison means identifying the significant components of treatment.

\section{Results and discussion}

Number of pods plant $^{-1}$
Levels of $\mathrm{P}_{2} \mathrm{O}_{5}$ and cultivars, as well as their interaction had significant effect on number of pods plant ${ }^{-1}$. Mean values of the data showed that plots treated with $80 \mathrm{~kg} \mathrm{P}_{2} \mathrm{O}_{5}$ $\mathrm{ha}^{-1}$ produced optimum number of pods plant $^{-1}$ (22), while the minimum number of pods plant $^{-1}$ (15) was recorded in control plot. These results are correlated with that of [17] who reported that $\mathrm{P}_{2} \mathrm{O}_{5}$ induced significantly increased pods plant ${ }^{-1}$. [18, 24] also reported that $\mathrm{P}_{2} \mathrm{O}_{5}$ at the rate of 75 $\mathrm{kg}^{-1}$ had significantly increased the number of pods plant $^{-1}$. Similarly mungbean cultivars had significant effects on the number of pods ${ }^{-1}$ plant. SWAT-I cultivars produced more number of pods ${ }^{-1}$ plant (20), while the lowest (18) was produced by NM54. These results are supported by [19] found that improved mungbean cultivars produced more number of pods plant ${ }^{-1}$ than local cultivars. The difference between cultivars might be due to genetic makeup and could be specialized root system of the improved cultivar responded for nutrient absorption. Interaction of Phosphorus $\mathrm{x}$ cultivars indicated that pods plant $^{-1}$ of all cultivars increased with increasing $\mathrm{P}_{2} \mathrm{O}_{5}$ levels up to $80 \mathrm{~kg}^{-1}$, and further growth and development retarded with increase in $\mathrm{P}_{2} \mathrm{O}_{5}$ level. It was observed that SWAT-I produced more number of pods plant ${ }^{-1}$ as $\mathrm{P}_{2} \mathrm{O}_{5}$ level increase up to 80 $\mathrm{kg} \mathrm{ha}^{-1}$. 
Imran et al.

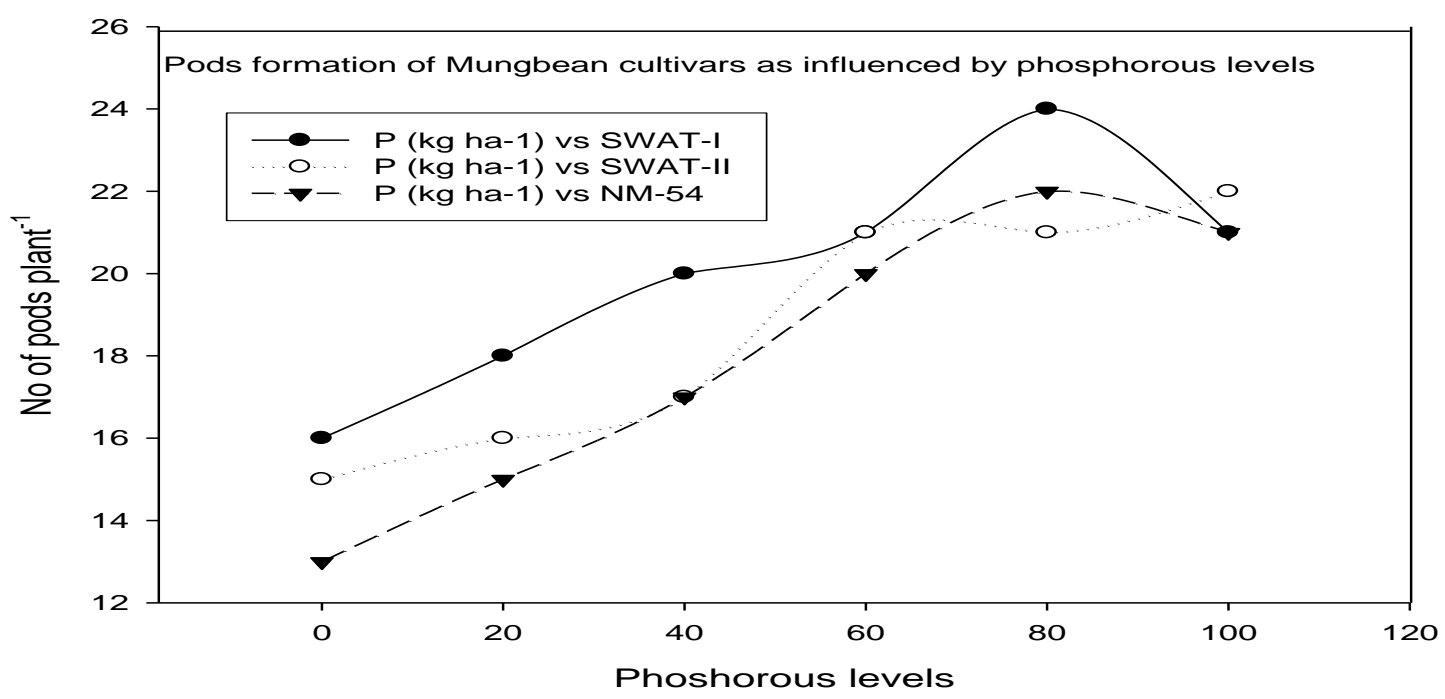

\section{Number of Seeds pod ${ }^{-1}$}

Statistical analysis of the data indicated that $\mathrm{P}_{2} \mathrm{O}_{5}$ levels and cultivars had significant effects on number seed $\operatorname{pod}^{-1}$. Number of seeds pod ${ }^{-1}$ was increased with increasing levels of $\mathrm{P}_{2} \mathrm{O}_{5}$. Means value of the $\mathrm{P}_{2} \mathrm{O}_{5}$ level indicated that plot treated with 80 or $100 \mathrm{~kg}_{2} \mathrm{O}_{5} \mathrm{ha}^{-1}$ produced maximum seeds pod $^{-1}$, while minimum (8) were recorded in the control plots. These results are supported by [17] who reported significant differences in number of seeds pod ${ }^{-1}$ with various levels of $\mathrm{P}_{2} \mathrm{O}_{5}$.
Cultivar SWAT-I produced maximum seeds $\operatorname{pod}^{-1}$ (11), while the lowest (9) were produced by cultivar NM-54. These results are in agreement with those obtained by [19] who reported difference in number of seed pod $^{-1}$ between cultivars and could be due to genetically determined differences in absorption of nutrients, especially $\mathrm{P}_{2} \mathrm{O}_{5}$. All mungbean cultivars produced maximum number of seeds pod $^{-1}$ with increasing $\mathrm{P}_{2} \mathrm{O}_{5}$ levels up to $80 \mathrm{~kg} \mathrm{ha}^{-1}$, further increase in $\mathrm{P}_{2} \mathrm{O}_{5}$ level decreased number of seeds pod $^{-1}$. 
No of seeds per pod of Mungbean cultivars as influenced by phosphorous levels

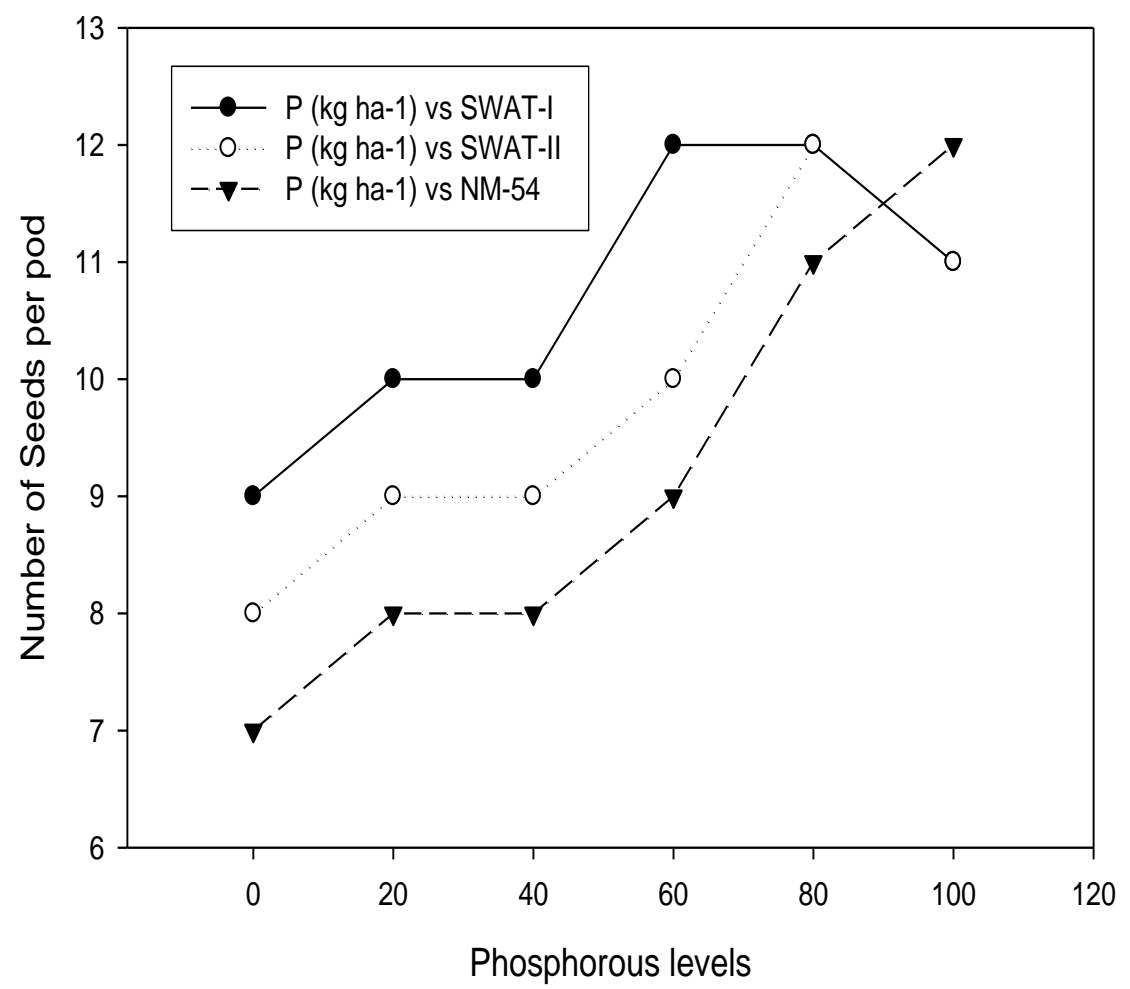

\section{Thousand seed weight (g)}

Statistical analysis of the data showed that the levels of $\mathrm{P}_{2} \mathrm{O}_{5}$ and cultivars had significant effects on number of seed pod 1. Plots treated with $80 \mathrm{~kg} \mathrm{P}_{2} \mathrm{O}_{5} \mathrm{ha}^{-1}$ produced heavier seeds $(40.2 \mathrm{~g})$ to be at par with $100 \mathrm{~kg} \mathrm{P}_{2} \mathrm{O}_{5} \mathrm{ha}^{-1}$, while less weight $(34.5 \mathrm{~g})$ was recorded in control plants. These results are in agreement with those obtained by [21] who reported that increasing $\mathrm{P}_{2} \mathrm{O}_{5}$ application up to $75 \mathrm{~kg} \mathrm{ha}^{-1}$ significantly increased the seed weight as compared with control plots. The mean values of mungbean cultivars indicated that SWAT-I produced heavier seeds (38.4 g), while the lighter seeds (35.9 grams) was produced by NM-54. The results were similar to that of [20] who reported that the differences between the 1000 seed weight in these cultivars may be due to hereditary superiority, growth rate, crop yield potential, the highest nutrient translocation, assimilation and dry matter partitioning. All mungbean cultivars produced heavier 1000 seed weight with increasing $\mathrm{P}_{2} \mathrm{O}_{5}$ level up to $80 \mathrm{~kg} \mathrm{ha}^{-1}$ further increased in $\mathrm{P}_{2} \mathrm{O}_{5}$ level, 1000 seed weight was decreased. However a linear increase was recorded for 1000-seed weight of SWAT-I cultivars with increased $\mathrm{P}_{2} \mathrm{O}_{5}$ levels up to $80 \mathrm{~kg} \mathrm{ha}^{-1}$. 


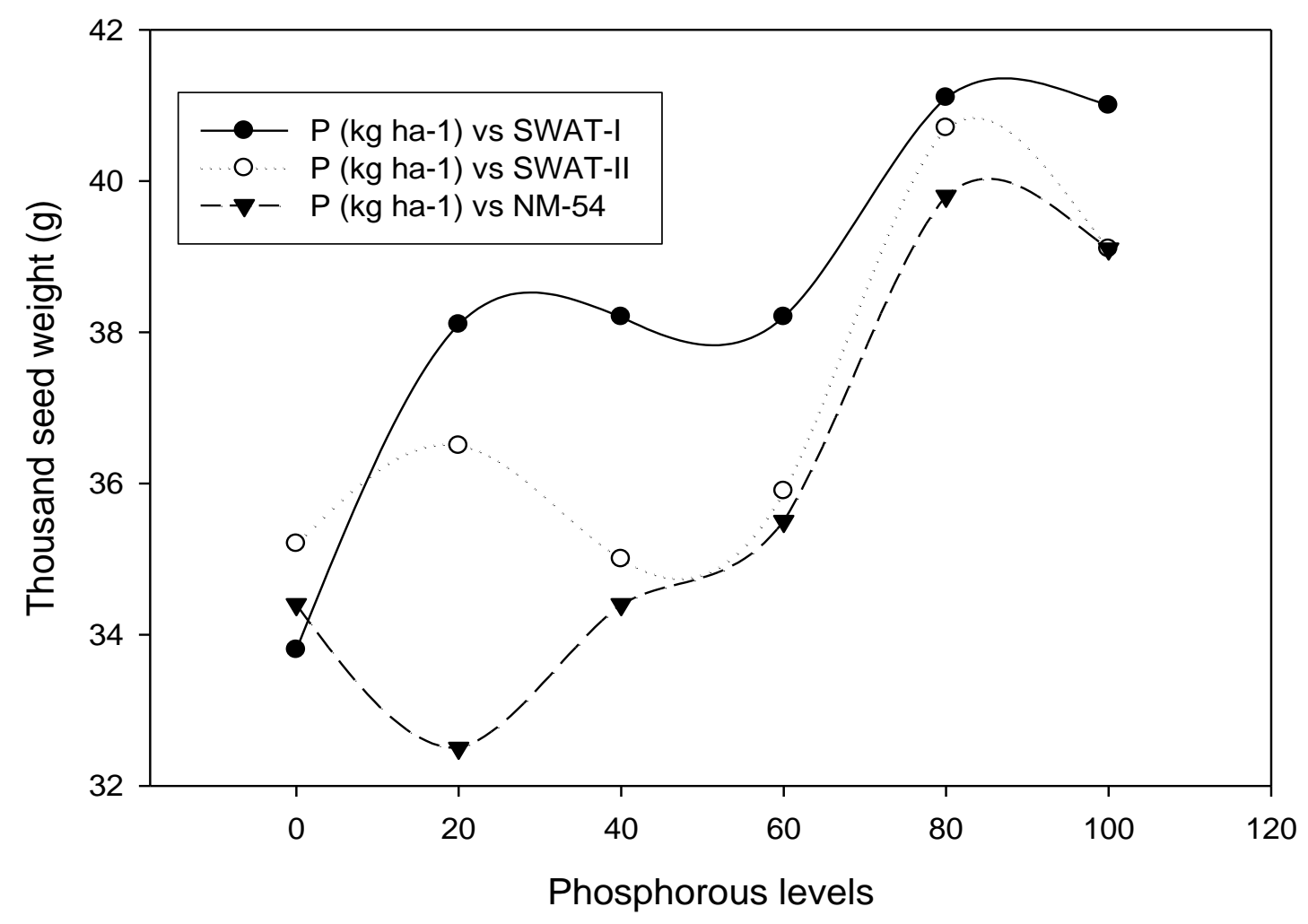

\section{Number of nodules plants ${ }^{-1}$}

The data indicated that the levels of $\mathrm{P}_{2} \mathrm{O}_{5}$ and cultivars had significant effects on the number of nodules per plant, while the interaction between phosphorus $\mathrm{x}$ cultivars had non-significant effect on the number of nodules plants ${ }^{-1}$. Mean data values showed that plots treated with $80 \mathrm{~kg} \mathrm{P}_{2} \mathrm{O}_{5} \mathrm{ha}^{-1}$ produced optimum number of nodules per plant (25), while minimum number (11,) was recorded in control plots. These results are in agreement with those obtained by [15, $22,24]$ who reported that application $\mathrm{P}_{2} \mathrm{O}_{5}$ promotes the early formation of the root and the formation of fibrous roots and lateral which had a positive effect on nodules plant ${ }^{-}$ ${ }^{1}$. Mungbean cultivars had significant effects on the number of nodules plant ${ }^{-1}$. SWAT-I mungbean cultivars produced more number of nodules plant ${ }^{-1}(21)$, while the lowest number of nodules plants ${ }^{-1}$ (18) was produced by NM-54. These results were supported by [16] who found that improved mungbean cultivars produced more number of nodules plant ${ }^{-1}$ than local cultivars. The differences between cultivars could be due to absorption of nutrients and genetic makeup. 


\section{Nodulation influenced by $\mathrm{P}$ levels in mungbean cultivars}

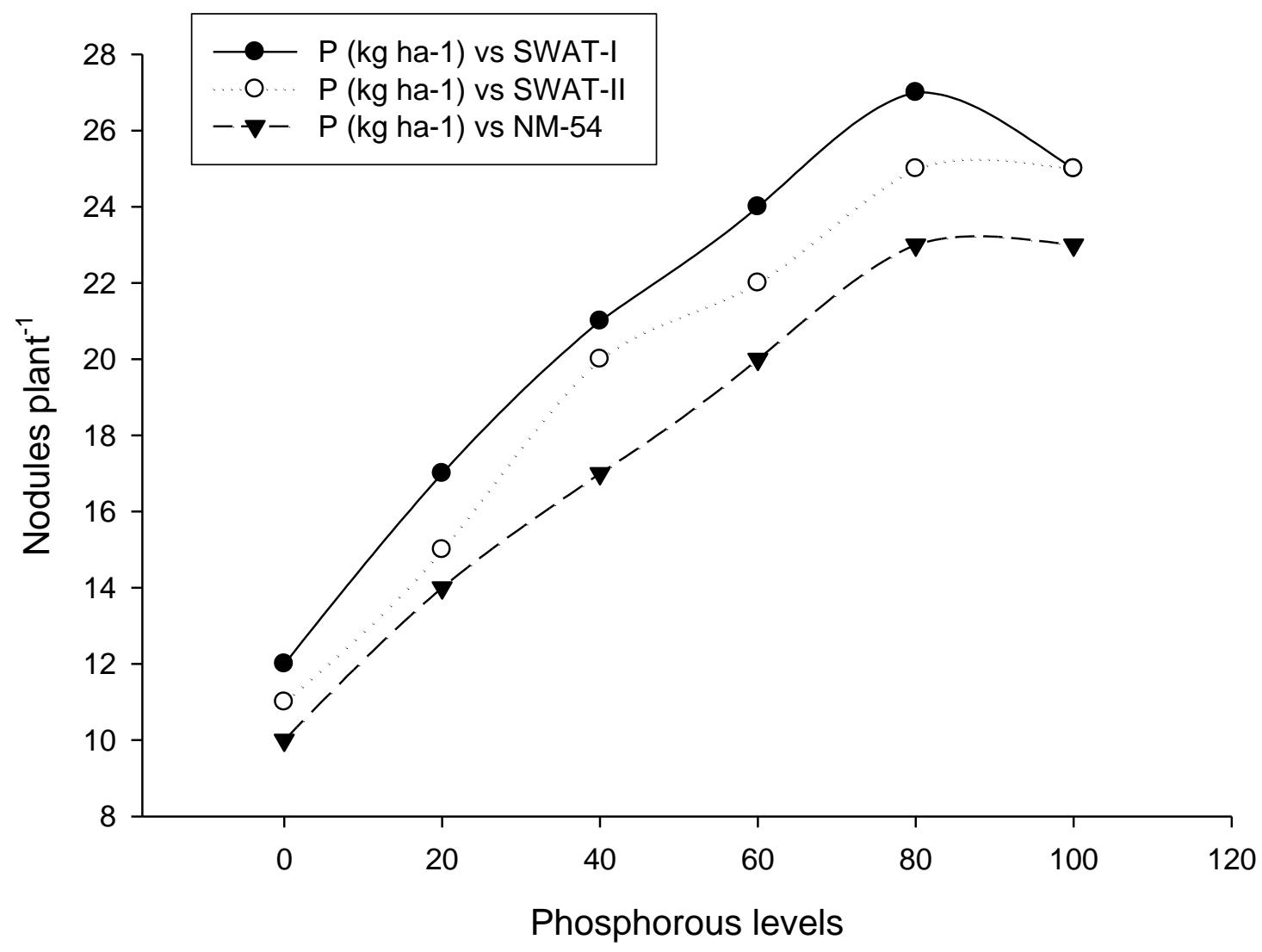

\section{Days to first pod formation}

Data revealed that phosphorus $\left(\mathrm{P}_{2} \mathrm{O}_{5}\right)$ levels and mungbean varieties (V) significantly affected days to first pod formation, while interaction between $\mathrm{P} \times \mathrm{V}$ had not significant effect on days to pod formation. Mean value of the data showed that plots applied $\mathrm{P}_{2} \mathrm{O}_{5}$ at the rate of 80 and $100 \mathrm{~kg} \mathrm{ha}^{-}$
${ }^{1}$ took less days (48 days) to pod formation, while more days (52 days) to pod formation were recorded in plots received no phosphorus. In case of varieties NM-54 took less days (49 days) while Swat-I were statistically at par by taking (50 days) to pod formation.

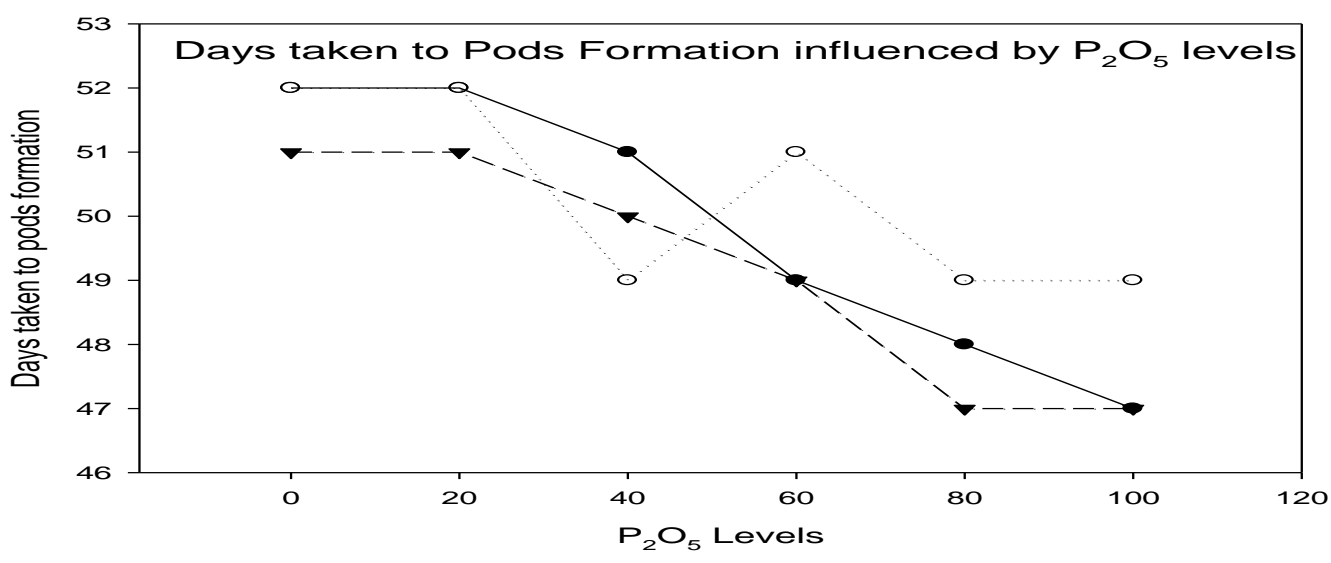




\section{Seed yield (kg ha-1)}

Seed yield was significantly influenced by $\mathrm{P}_{2} \mathrm{O}_{5}$ levels and mungbean cultivars, as well as their interaction. The value of $\mathrm{P}_{2} \mathrm{O}_{5}$ levels indicated that plants treated with $80 \mathrm{~kg} \mathrm{P}_{2} \mathrm{O}_{5} \mathrm{ha}^{-1}$ produced maximum seed yield (1139 $\left.\mathrm{kg} \mathrm{ha}^{-1}\right)$ having at par with $100 \mathrm{~kg} \mathrm{P}_{2} \mathrm{O}_{5} \mathrm{ha}^{-1}$, while minimum seed yield $\left(617 \mathrm{~kg} \mathrm{ha}^{-1}\right)$ was recorded in control plots. These results are in connection with those obtained by $[16,24]$ who reported that increase in yield of mungbean with increasing level of $\mathrm{P}_{2} \mathrm{O}_{5}$ up to $75 \mathrm{~kg} \mathrm{ha}^{-1}$ further increase in $\mathrm{P}_{2} \mathrm{O}_{5}$ level slightly decreased the seed yield. The increase in yield of mungbean may be due to $\mathrm{P}_{2} \mathrm{O}_{5}$ application has been attributed to the deep branching, better fruiting, increase in the number of seeds pod ${ }^{-1}$ and hence heavier seeds of mungbean yield increased accordingly compared with control plants [24]. Mungbean cultivar significantly influenced the seed yield. Cultivars NM-54 produced maximum seed yield $\mathrm{kg} \mathrm{ha}^{-1}$ (1030), while the minimum seed yield $\mathrm{kg}$ $\mathrm{ha}^{-1}$ (799) was produced by cultivar NM54. These results are in agreement with [18] who reported that the differences between the performance of these cultivars might be due to hereditary superiority, growth rate, crop yield potential, higher nutrient translocation, assimilation and dry matter partitioning. However a linear increase was recorded for seed yield when cultivars SWAT-I treated with $80 \mathrm{~kg} \mathrm{P} \mathrm{ha}^{-1}$.

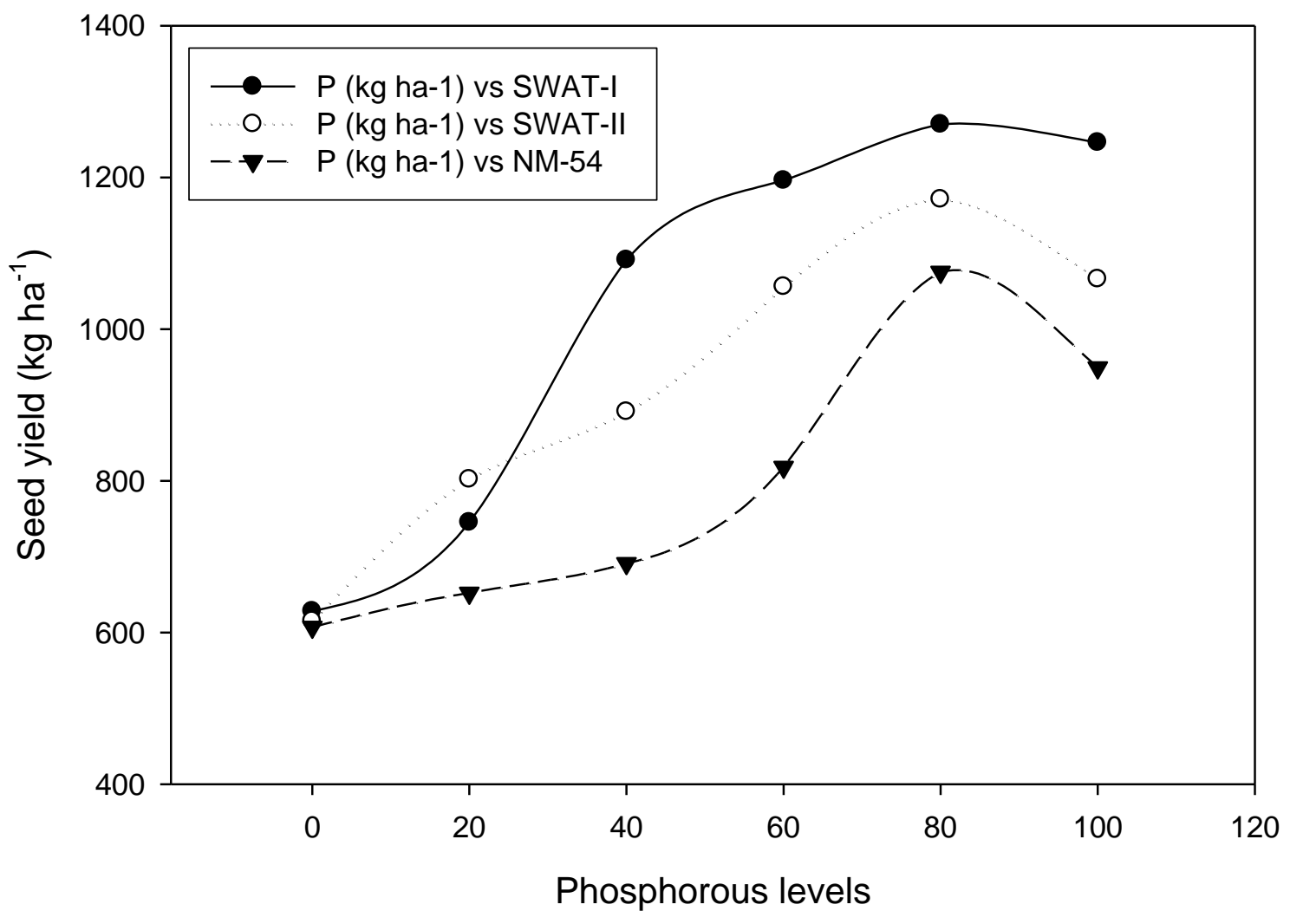




\section{Harvest index (\%)}

Statistical data Analysis of the harvest index showed that $\mathrm{P}_{2} \mathrm{O}_{5}$ and mungbean cultivar (C) had significant effect on the H.I \%, however their interaction $(\mathrm{P} \times \mathrm{C})$ was not significant. With increasing $\mathrm{P}_{2} \mathrm{O}_{5}$ level, harvest index significantly increased in those plots treated with $80 \mathrm{~kg} \mathrm{P}_{2} \mathrm{O}_{5} \mathrm{ha}^{-1}$ and produced maximum harvest index (28.6\%) at par valued with $100 \mathrm{~kg} \mathrm{P} \mathrm{ha}{ }^{-1}$, while minimum harvest index $(23.1 \%)$ was recorded in control plots. These results were supported by the findings of [21] who reported that rising index rate of $\mathrm{P}_{2} \mathrm{O}_{5}$ application significantly increased above control plots. SWAT-I cultivar found with maximum harvest index $(28.2 \%)$, while the NM-54 cultivars produced harvest index (24.2 \%).This might be due to their phenotypic and genetic as well as hereditary superiority and hence the difference possess from other cultivars of mungbean in term of H.I.

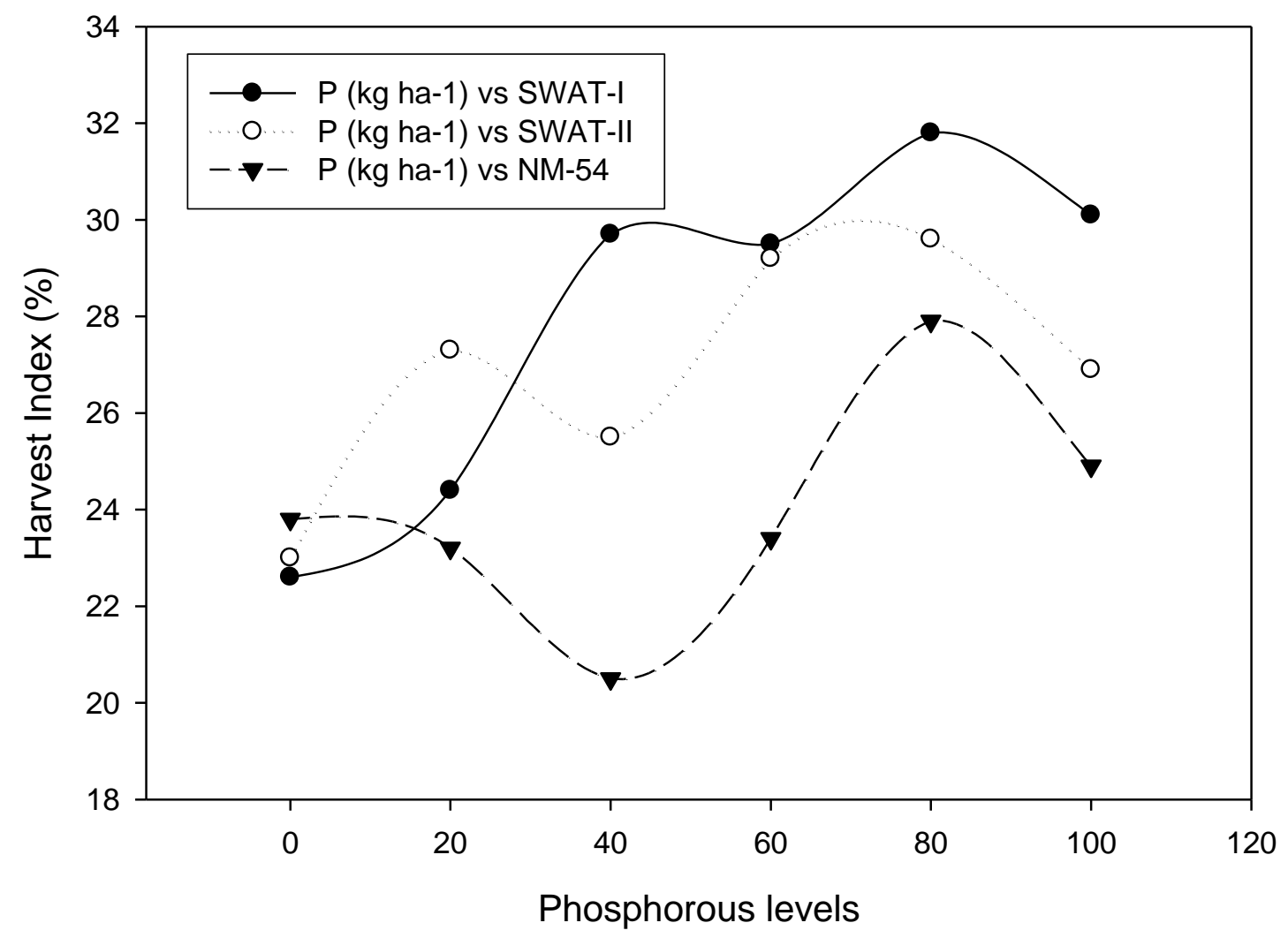

\section{Conclusion}

Optimum roots nodulation increases soil fertility and hence reduce the input cost of the farmers which leads the farmers towards socio economic stability. Therefore on the basis of above results it was concluded that SWAT-I treated with $80 \quad \mathrm{~kg} \quad \mathrm{P}_{2} \mathrm{O}_{5} \mathrm{ha}^{-1}$ produced maximum roots nodule, maximum pods plant ${ }^{-1}$, seeds pod ${ }^{-1}, 1000$ seed weight, seed yield and harvest index. On the basis of above results, it is recommended that SWAT-I cultivars should be planted with 80 $\mathrm{kg} \mathrm{P}_{2} \mathrm{O}_{5} \mathrm{ha}^{-1}$ application under the agro climatic condition of the Swat Valley for increasing seed yield and optimum nodulation to enhance soil fertility.

\section{Authors' contributions}

Design the experiment, data collection and analysis: Imran, I Hussain, I khattak, \& A Rehman. 
Downloaded the related review, data collection and interpretation of the data: F Ahmad, H Zada.

Technical help, weeds identification and correction11. Mitra S, Rhattacharya S K, Dini M \& Braschi S of the manuscript: S Naveed, H Zada and F Ahmad. Wrote the paper: Imran

\section{References}

1. Sarwar G, Sadiq M S, Sally M \& Abbas G 2004.

Selection criteria in F3 and F4 of mungbean12. Vigna radiata 1. Wilczek. Pak. J. bot.36, paragraph 2: 297-310.

2. Frauque A, Hirota Haraguchi $\mathrm{O} T$ and .A. Rahman M 2000. Growth analysis, yield and canopy structure in, mungbean-maize intercropping. Bu. Inst. of Tropical agricultural13. Khan M A, Taj Baloch \& Gandapur M S Kyushu University, Fukuoka, Japan, 23: 61-69.

3. Khattak G S S, Ashraf M \& Khan M S 2004. Evaluation of genetic variability for yield and yield components in mungbeanVigna radiata 14. ((1.) Wilczek) using the average generation analysis. Pak. J. bot., 36: 583-588.

4. MINFA 2012. Agriculture statistics of Pakistan, Ministry of food, agriculture and livestock, 15 Govt of Pakistan, Islamabad.

5. Arya M P S \& Galperti K 1988. The effect of doses of P2O5 on the growth, yield and quality of mungbean and soil nitrogen in the summer. IND. J. Agri. RES: 23-30.

6. Dewangan M K, Perrone N \& Tripathy R S R S16. 1992. Effect of P2O5, spacing and irrigation on yield and protein concentration NP summer green gram. Annals of RIS. Agri, 13, paragraph 3: 280-281.

7. Raboy V 2003. Molecules of interest: myoinositol-hexakisphosphate 6-1-. 64: 103317 PHYTOCHEM-1043.

8. Batjes N H 1997. A world of data sets derived soil properties by Fao-UNESCO soil for global modelling. Manage land use.

9. Khan Demi, Qasim M \& Jamil M 2004. Effect of $\mathrm{Zn}$ content of rice starch and zinc content of soil, root and leaf of rice grown in calcareous 18 . soils. Int j. agric Biol, 6: 1132-1135.

10. Hossain M A \& Hamid A 2007. Influence of the application of $\mathrm{N}$ and $\mathrm{P}$ fertilizers on the growth of roots, leaf photosynthesis and yield 19 . performance of mungbean. Bangladesh RIS. J. Agri presupposed: 369-374.

1999. Effect of variety, rock phosphate and phosphate solubilizing bacteria on growth and productivity of green gram in acid soils of Tripura. Env. Eco. 17: 926-930.

Ayub M A, Tucciarone M A Hull, Amin M M Z \& Murtaza G 1999. Growth and yield of rrtungbean response (Vigna radiata 1.) Cultivars at different levels of nitrogen. Pak. J. Bio. SIC. 2: 1378-1380.

1999. Effect of P2O5 on the growth and yield of mungbean. Pak. J. Bio. 2: 667669.

Warsi, M Yadai \& A S 1988. Performance of summer planted mungbean on irrigation and plant density. Indian J. Agron., 33: $19-21$.

Bhuiyan M M H, Rahman M M, glory F, Sutradhar G N C \& M S I 2008 Bhuiyan. Effect of P2O5, molybdenum and Rhizobium inoculation on growth and for nodulation of mungbean. J.Suolo.Natura. 2, paragraph 2: 25-30.

Hussain F, Malik A U, Haji M A \& Monaco A L 2001. The growth and yield response of two cultivars of mungbean (vign radiata 1 .) at different levels of potassium. A. of J. P. SIC. imperative: 622-625.

Malik M A, Hussain S, Habib E A, Warraich A \& Andrea S 2004. Effect of seed inoculation and P2O5 application on growth, yield and seed quality of mungbean (Vigna radiata 1.) HP SWAT-I. Inter J. Agri. Bio. 515 (4): 1560-8530.

Imran., A. A. Khan, F. Ahmad.2015. Yield and yield attributes of mungbean cultivars as affected by $\mathrm{P}$ levels under different tillage system.

Imran, A A Khan, F Ahmad 2015. Yield and yield attributes of mungbean 
cultivars as affected by $\mathrm{P}$ levels under different tillage system.

20. Urso M S, Amin A M K R, Ullah M J \& Asaduzzman M 2009. The interaction effect of different varieties and fertilizers on growth and yield of summer mungbean. American-Eurasian J. Agron. 2 (3): 180-184.

21. Kumar R, Singh Y V, Singh S, Latare A M, Mishra P K \& Nola 2012. Effect of P2O5 and sulphur nutrition on yield, yield attributes of mungbean (Vigna radiata 1 . Wilczek). Journal of chemical and pharmaceutical research, 2012, 5: 25732571.
22. Naeem M, Ahmed S \& Cheema Z A 2000. Mungbean yield as affected by different durations of weed competition under high P2O5 Status. Inter J. Agric. Bio. 1560 (2): 133-135.

23. Statistix., Statistix for Windows analytical software, version 8.0, USA (2005).

24. Imran and A. A. Khan. 2015. Grain Yield and Phenology of Maize Cultivars Influenced by Various Phosphorus Sources.J. Food Sci and Q. Mang. 37. 74-78. 